\title{
REVIEW ON PLANTS MAINLY USED FOR THE PREPARATION OF KSHAR SUTRA
}

\author{
Murali Krishna $\mathrm{C}^{1^{*}}$, Gupta $\mathrm{V}^{2}$, Bansal $\mathrm{P}^{3}$, Kumar $\mathrm{S}^{4}$, Sannd $\mathrm{R}^{2}$, Narayana $\mathrm{A}^{1}$
}

\begin{abstract}
Many herbal remedies individually or in combination have been recommended in various medical treatises for the cure of different diseases. Ksharsutra- an Ayurvedic para-surgical measure is used the treatment of Nadi Vrana (sinus), Bhagandara (fistula- in - ano), arbuda (excision of small benign tumour) etc. by using different medicinal plants. The standard kshar sutra is prepared by using snuhi ksheera (latex of Euphorbia nerrifolia Linn), apamarg kshar (water extract of ashes of Achyranthus aspera Linn plant) and haridra powder (powder of Curcuma longa $L$ ). This review mainly focuses on the plants that are used in preparation of Ksharsutra so that more research work is carried out in the direction of standardization, therapeutic level determination of Ksharsutra plants.
\end{abstract}

Keywords: Kshar Sutra, para-surgical measure, Fistula-in-ano, Euphorbia nerrifolia Linn, Achyranthus aspera Linn, Curcuma longa L

\section{Introduction}

Ayurveda is the most ancient health care system and is practiced widely in India, Sri Lanka and other countries. According to the WHO survey $80 \%$ of the populations living in the developing countries rely almost exclusively on traditional medicine for their primary health care needs. Exploration of the chemical constituents of the plants and pharmacological screening may provide us the basis for developing the leads for development of novel agents. In addition, herbs have provided us some of the very important life saving drugs used in the armamentarium of modern medicine. However, among the estimated 250,000400,000 plant species, only $6 \%$ have been studied for biological activity, and about $15 \%$ have been investigated phytochemically(1). Kshar Sutra is a Sanskrit phrase in which Kshar refers to anything that is corrosive or caustic; while Sutra means a yarn or thread (The origin of the English word "Sew"). It is described in one of the most ancient medicine known to mankind that is - Ayurved, which originated and flourished in India. Ayurveda is still at its peak in India and gaining a great popularity worldwide. The Ksharsutra was first mentioned by the "Father of Surgery" Sushruta in his text named SUSHRUT - SAMHITA for the treatment of Nadi Vrana (sinus), Bhagandara (fistula- in - ano), arbuda (excision of small benign tumour) etc. Although Brihattrayi- the chief three texts of Ayurveda mention the use of kshara sutra, there is no description of their preparation. It was Chakrapani Dutta in late eleventh century who has mentioned in his book Chakradatta, the method of preparation with a clear-cut indication of its use in bhagandara and arsha (haemorrhoid) for the first time. He explains the method that by smearing a sutra (thread) repeatedly in the latex of snuhi and haridra (turmeric) powder makes the kshara sutra. Later authors like Bhavamishra, Bhaisajyaratnavali etc. also mention the same method. But because of brevity of preparation and inadequate explanation of procedure of application, it

1. National Institute of Indian Medical Heritage, Hyderabad, India, 2. National Institute of Ayurvedic Pharmaceutical Research, Patiala, India, 3. Baba Farid University of Health Sciences, Faridkot, India, 4. Central Research Institute of Ayurveda, New Delhi, India

*Corresponding Author: Research Officer (Ayurveda), National Institute of Indian Medical Heritage, Hyderabad, India, Tel: +919652281514, E.mail: mkchagamreddy@yahoo.com, 
lost its popularity among Ayurvedic surgeons (2-4).

\section{Types of Kshar Sutra}

In the textual reference of Chakradatta and Rasatarangini we get only indication of the thread made up of Snuhi, apamarga and Turmeric. Susruta describes about many kind of Kshars like Karaveera, Palasa, Kadali etc. in Susruta Samhita. So many studies have already carried out with variations in the Kshara and the latex. The most remarkable are Guggulu Ksharasutra, Udumbara Ksharasutra, Gomutra Ksharasutra, Papaya Ksharasutra, Ksharasutra prepared with Ficus carica latex etc (4-5).

\section{Method of Preparation}

The standard kshar sutra is prepared by repeated coatings of snuhi ksheera (latex of Euphorbia Nerrifolia Linn), apamarg kshar (water extract of ashes of Achyranthus aspera Linn plant) and haridra powder over a surgical linen thread no. 20. This thread is spread throughout lengthwise in hangers. Each thread on the hanger is then smeared with snuhi latex with the help of gauze piece soaked in the latex.

Kshara sutra cabinet has a source of hot air with regulated temperature to dry the thread and an Ultra Violet light that is used for sterilization. This wet hanger is transferred in kshar sutra cabinet for drying and sterilization. Same process is repeated next day. Eleven such coatings with snuhi ksheera alone should be accomplished. The twelfth coating is done by first smearing the thread with ksheera and in wet condition thread is passed through the apamarg kshar. It is again transfer into the cabinet for drying and sterilization. This process is repeated till seven coatings of snuhi ksheer and apamarg kshar is achieved. Final three coating are completed with snuhi ksheera and fine powder of turmeric in the same fashion. Thus twenty-one coatings over the thread are completed (6).

\section{Mode of Action}

Kshar Sutra is now a popular treatment modality in India for the management of fistula in ano. Many Clinical trials have been carried out in different institutes to evaluate the action of Kshara sutra in various disease conditions. The countries like Srilanka and Japan have also conducted many clinical trials and established the action of this thread. According to Ayurveda the action of Kshar sutra is thought to be due to its healing and cleansing effect in the local area where it is applied. It can be suggested that due to the anti microbial action and as a saton it allows the proper drainage of pus from the fistula that leads to a proper healing. On the other hand the cutting effect of thread incises the skin gradually without a surgical incision. Many studies confirm that it is more effective in the way of reducing hospital stay and less infection than the conventional saton therapy. Researchers suggest that it is having the action of Excision, Scrapping, Draining, Penetrating, Debridement, Sclerosing, Healing, Bactericidal and Bacteriostatic (6).

\section{Euphorbia neriifolia $\mathbf{L}$.} Euphorbia neriifolia Linn (Euphorbiaceae) is found throughout the Deccan Peninsula of India and commonly occurs in the dry hilly rocky grounds of north, central and south India. It is an herb full of spine, and is popularly known as sehund or thohar in Hindi. Ayurveda describes the plant as bitter, pungent, laxative, carminative, improves appetite, as well as useful in abdominal problems, bronchitis, tumours, loss of onsciousness, delirium, leucoderma, piles, inflammation, enlargement of spleen, anaemia, ulcers and fever. Its leaves, in the Indian traditional system, are used as aphrodisiac, diuretic, and also in cough and cold, bleeding piles and ano-rectal fistula (7). Plants of euphorbia species show anticarcinogenic activity due to the presence of several terpenes, anthocyanins, alcohols and 
steroids; diterpenoid ingenol 3,20dibenzoate and phorbol 12-tiglate 13decanoate isolated from Euphorbiaceae plants show antileukaemic activity against the P-388 lymphocytic leukaemia in mice (8). Euphol, a triterpene alcohol from the roots of Euphorbia kansui, has inhibitory activity against mice skin tumour (9). E. neriifolia, being widely available in large quantities, is potentially a low-cost source of active therapeutic substances. We have previously reported on the mild CNS depressant, wound healing and immunomodulatory activities of the hydroalcohol leaf extract (10-12). Little phytopharmacological work, however, has been done on the medicinal application of the leaf. Saponin isolated from the leaf possesses good haemolytic and in-vitro antioxidant activity but it is devoid of antibacterial activity up to $10 \mathrm{mg} / \mathrm{ml}$ concentration (13). Euphorbia neriifolia leaves are used as aphrodisiac, diuretic and also used in the treatment of bronchitis, bleeding piles and in ano-rectal fistula. The tribal population of Chattishgarh region uses the milky latex as an ingredient of aphrodisiac mixture $(7,14)$. The aqueous extract of the latex of Euphorbia neriifolia facilitated the wound healing process as evidenced by increase in tensile strength, DNA content, epithelization and angiogenesis (15). E. neriifolia Leaf is rich in crude sapogenin, and euphol $(0.023 \%)$ was identified as a major constituent. The sapogenin fraction showed antioxidant, radioprotective and cytotoxic activity against malignant melanoma cells (16). Natives of Chhattisgarh use externally boiled 'thohar' milk in castor oil with salt to cure the deep cracks in soles of legs. The milk of 'thohar' is also used commonly like aloe gel in case of burns. 'thohar' milk can be used successfully for healing of wounds. Application of lukewarm 'thohar' leaves reduces itching pain and swelling in piles (17). E. neriifolia hydroalcoholic extract was found to contain sugar, tannins, flavonoids, alkaloids triterpenoidal saponin on preliminary phytochemical analysis. Several triterpenoids like Glut-5en-3\$-ol, Glut 5(10)-en-1-one, taraxerol and \$-amyrin has been isolated from powdered plant, stem and leaves of $E$. neriifolia (18-19). Antiquorin have been isolated from ethanol extract of fresh root of E. neriifolia (20). Neriifolione, a triterpene and a new tetracyclic triterpene named as nerifoliene along with euphol were isolated from the latex of $E$. neriifolia (21).

\section{Achyranthes aspera L.}

Achyranthes aspera Linn. (Amaranthaceae,) is commonly found as a weed on way side and at waste places throughout India. The plant is reported to yield a water-soluble base and a chloroform soluble base. The former was earlier designated as achyranthine (22). It was characterized as a betaine derivative of N-methylpyrrolidine-3-carboxylic acid (22). Later studies showed that the watersoluble base was betaine and not achyranthine (23). The chloroform soluble basic fraction was shown to be a mixer of two uncharacterized alkaloid entities (24). The ethanol extract of the plant contained alkaloids and saponins while flavonoids and tannin were found absent (25). The shoot yielded a new aliphatic dihydroxyketone, characterized as $36,47-$ dihydroxyhenpentacontan- 4 one together with tritriacontanol (26). An essential oil; a new long chain alcohol characterized as 17-pentatriacontanol four new compounds characterized as 27cyclohexylheptacosan-7-ol, 16-hydroxy-26 methylheptacosan- 2-one, 4methylheptatriacont-1-en-10-ol and tetracontanol-2 (27-28). The chloroform extract of the stem led to the isolation of $n$ pentatriacontan, 6-pentatriacontanone, hexatriacontane and triacontane (29). The inflorescence is reported to contain flavonoids and alkaloids (30). The defatted seeds are reported to yield a saponin in a yield of $2 \%$, which was identified as oleanolic acid- oligosaccharide. The sugar 
moiety of the saponin was composed of glucose, galactose, xylose and rhamnose (31-33). Isolated a crude sapogenin fraction from the seeds yielded oleanolic acid (34). Later, investigation led to the isolation of two oleanolic acid based saponins, saponin A and saponin B which were characterized as $\alpha-\mathrm{L}$ rhamnopyranosyl $\quad(1 \rightarrow 4)-\beta^{\prime}-\mathrm{D}-$ glucopyranosyl $\quad(1 \rightarrow 4)-\beta^{\prime}-\mathrm{D}$ glucuronopyranosyl ( $1 \rightarrow 3$ )-oleanolic acid and $\beta$-D-galactopyranosyl $(1 \rightarrow 28)$ ester of saponin A, respectively (35). In another study, the total saponins were hydrolysed with acid and the genin was identified as oleanolic acid (35). A rapid procedure for the separation of triterpenoid saponin based on partition chromatography from the plant has been described (36). The seeds are reported to contain hexatriacontane, 10- octacosanone, 10triacosanone and 4-triacontanone (29). The root of the plant was found to contain alkaloids but indicated absence of saponin and tannins (37-38). In yet another preliminary chemical study, the root was reported to contain alkaloids, flavonoids, saponins, steroids and terpenoids. Glycosides were found to be absent (39). Isolation of $\beta$ - sitosterol was also reported from the root (38). Various parts of the plant, viz., seeds, stem, leaves and root are reported to contain ecdysterone (40-41). A new six compound isolated from the ethanol extract of the roots are strigmasta5,22 dien-3- $\beta$-ol, trans-13-docasenoic acid, n-hexacosanyl n-decaniate, nhexacos-17-enoic acid, n-hexacos-11enoic acid and n-hexacos-14-enoic acid (38). Achyranthes aspera showed various pharmacological activity like Antimicrobial activity (42-26), Anti inflammatory activity (47-49), Immunomodulatory activity (50-54), Anti fertility activity (55-65), Antihyperlipidemic activity (66), Anti-feedant activity (67), Anti-diabetic activity (6869), Diuretic activity (70), Cardiovascular system activity (71-73), Anti-carcinogenic activity (74), analgesic and antipyretic (75).

\section{Curcuma longa $\mathrm{L}$.}

Curcuma longa L. (Zingiberaceae) family is a medicinal plant extensively used in Ayurveda, Unani and Siddha medicine as home remedy for various diseases (76-77). C. longa L., botanically related to ginger, is a perennial plant having a short stem with large oblong leaves and bears ovate, pyriform or oblong rhizomes, which are often branched and brownish-yellow in colour (76). Traditional uses turmeric powder for the treatment of biliary disorders, anorexia, coryza, cough, diabetic wounds, hepatic disorders, rheumatism and sinusitis (78). In China, $C$. longa is used for diseases associated with abdominal pains (79). Curcumin, the ethanol extract of the rhizomes, sodium curcuminate, [feruloyl(4-hydroxycinnamoyl)- methane] (FHM) and [bis-(4-hydroxycinnamoyl)- methane] (BHM) and their derivatives, have high antiinflammatory activity against carrageenin-induced rat paw oedema (8081). Curcumin is also effective in formalininduced arthritis (80). Curcumin reduces intestinal gas formation (81) and carbon tetrachloride and Dgalactosamineinduced glutamate oxaloacetate transaminase and glutamate pyruvate transaminase levels (82-83). It also increases bile secretion in anaesthetized dogs (84) and rats (85), and elevates the activity of pancreatic lipase, amylase, trypsin and chymotrypsin (86). Curcumin protects isoproterenol-induced myocardial infarction in rats (87). Curcumin, FHM and BHM also have anticoagulant activity (88-89). Curcumin and an ether extract of $C$. longa have hypolipemic action in rats (90) and lower cholesterol, fatty acids and triglycerides in alcohol induced toxicity (91). Curcumin is also reported to have antibacterial (81), antiamoebic (92) and anti HIV activities (93). Curcumin also shows antioxidant activity (94-97). It also shows antitumour (98-100) and anticarcinogenic (101-104) 
activities. The volatile oil of $C$. longa shows anti-inflammatory (105), antibacterial (106-107) and antifungal activities (108). The petroleum ether extract of $C$. longa is reported to have antiinflammatory activity (108). Petroleum ether and aqueous extracts have 100\% antifertility effects in rats (109). Fifty per cent ethanolic extract of $C$. longa shows hypolipemic action in rats (110). Ethanolic extract also possesses antitumour activity (111). Alcoholic extract and sodium curcuminate can also offer antibacterial activity (81-84). The crude ether and chloroform extracts of $C$. longa stem are also reported to have antifungal effects (112). A C. longa fraction containing arturmerone has potent antivenom activity (113). C. longa also shows adjuvant chemoprotection in experimental forestomach and oral cancer models of Swiss mice and Syrian golden hamsters (114). Curcumin also increases mucin secretion in rabbits (115). Turmeric contains protein, fat, minerals, carbohydrates and moisture. The essential oil obtained by steam distillation of rhizomes has $a$-phellandrene, sabinene, cineol, borneol, zingiberene and sesquiterpenes. Curcumin (diferuloylmethane) is responsible for the yellow colour, and comprises curcumin I, curcumin II and curcumin III (116-119).

\section{CONCLUSION}

Major thrust by whole of the pharmaceutical industry is focused towards design and development of new innovative/indigenous plant based drugs through investigation of leads from traditional system of medicine. In recent years, ethno-botanical and traditional uses of natural compounds, especially of plant origin received much attention as they are well tested for their efficacy and generally believed to be safe for human use. Thorough screening of literature available on Kshar sutra depicted the fact that it is a popular remedy among the various ethnic groups, Ayurvedic and traditional practitioners for treatment. Researchers are exploring the therapeutic potential of these plants as it has more therapeutic properties which are not known.

\section{REFERENCES}

1. Balandrin M.F, Klocke J.A, Wrtele E.S, Boilinger W.H. Content and purity of extract solasodine in some available species of Solanum. Science\& Culture. 1985; 56(5); 214216

2. Shukla N.K, Narang R, Nair N.G.K, Radhakrishna S, Satyavati G.V. Multicentric randomized controlled clinical studies of Kshara-sootra in management of fistula-in-ano. Indi J. Med. Res. (B). 1994; 177-185

3. Nishiguchi Y, Maida K, Hirakawa $\mathrm{H}$, Tazawa K. Kshara sutra treatment for anal fistula associated with Chron's disease. Surgery. 2003; 57; 81-85

4. Yoshimitu M, Mikage M, Nakagawa $\mathrm{Y}$, Yamamoto K, Tazawa K. The study of Kshara Part 2-Production of domestic Kshara Sutra in Japan. Journal of Traditional Medicines. 2004; 22 (1); 15-18

5. Ghanekar B.G. Susruta Samhita, Sutra Sthana 11ed. New Delhi; ML Publication; 1998

6. Sharma S.K, Sharma K.R, Singh K. Kshara Sutra Therapy in Fistula- in ano and other Ano- Rectal Disorders. New Delhi; R.A.V. Publication; 1995

7. Bigoniya P, Rana A.C. Comprehensive Phytopharmacological Review of Euphorbia neriifolia Linn. Pharmacognosy Review. 2008; 2(4); 57-66

8. Kupchan S.M, Uchida I, Branfman A.R, Dailey R.G Jr Fei B.Y. Antileukemic principles isolated from euphorbiaceae plants. Science. 1976; 191(4227); 571-572.

9. Yasukawa K, Akihisa T, Yoshida Z.Y. Inhibitory effect of euphol, a 
triterpene alcohol from the roots of Euphorbia kansui on tumor promotion by 12-otetradecanoylphorbol- 13 -acetate in two-stage carcinogenesis in mouse skin. J Pharm Pharmacol. 2002; 54(1); 119-124

10. Bigoniya P, Rana A.C. Psychopharmacological profile of hydro-alcoholic extract of Euphorbia neriifolia leaves in mice and rats. Indian J Exp Biol. 2005; 43; 859-862

11. Bigoniya P, Rana A.C. Wound healing activity of Euphorbia neriifolia leaf extract. $\mathrm{J}$ Nat Remedies. 2007; 7(1); 94-101

12. Bigoniya P, Rana A.C. Immunomodulatory activity of Euphorbia neriifolia leaf hydroalcoholic extract in rats. Ind Drugs. 2008; 45(2); 90-97

13. Bigoniya P, Rana A.C. Hemolytic and In-vitro Antioxidant Activity of Saponin Isolated from Euphorbia neriifolia Leaf. In: Recent Progress in Medicinal Plants, Natural Products - II. Vol. 2. Chapter-20; 2006. 359-376p

14. Kirtikar K.R, Basu B.D. Indian Medicinal Plants, II. Dehradun; International Book Distributors; 1996. 1581p

15. Rasik A.M, Shukla A, Patnaik B.N, Dhawan D.K, Srivastava K.S. Wound healing activity of latex of Euphorbia neriifolia. Indian Journal of Pharmacology. 1996; 28; 107-109

16. Bigoniya P, Rana A.C. Radioprotective and In-Vitro Cytotoxic Sapogenin from Euphorbia neriifolia (Euphorbiaceae) Leaf. Tropical Journal of Pharmaceutical Research. 2009; 8(6); 521-530

17. Anjaneyulu V, Ramachandra R. Crystallization principles of Euphorbiaceae. Part IV: Triterpenes from the stems and leaves of $E$. neriilfolia. Current Science. 1965; 34; 606-609
18. Chatterjee A, Saha S.K, Mukhopadhyay S. Lewis acidcatalysed rearrangement of glut-5en-3\$-y1 acetate and glut-5(10)-en3\$-y1 acetate. Indian J. Chem. 1978; 16(B); 1038-1039

19. $\mathrm{Ng}$ A.S. Diterpenes from Euphorbia neriifolia. Phytochem. 1998; 29; 662-664

20. Ilyas M, Praveen M, Amin K.M.Y. Neriifolione, a triterpene from Euphorbia neriifolia. Phytochemistry. 1998; 48; 561-563

21. Mallavadhani U.V, Satyanarayana K.V, Mahapatra A, Sudhakar A.V. A new tetracyclic triterpene from the latex of Euphorbia neriifolia. Natural Product Research. 2004; 18(1); 33-37

22. Basu N.K. The chemical constitution of achyranthine. J Proc Inst Chem. $1957 ; 29 ; 73-76$

23. Kapoor V.K, Singh H. Isolation of betain from Achyranthes aspera Linn. Ind J Chem. 1966; 4; 461-463

24. Kapoor V.K, Singh H. Investigation of Achyranthes aspera Linn. Ind J Pharm. 1967; 29; 285-288

25. Kumar S, Singh J.P, Kumar S. Phytochemical screening of some plants of Manipur-I. J Econ Bot Phytochem. 1990; 1; 13-16

26. Misra T.N, Singh R.S, Pandey H.S, Prasad C, Singh B.P. Antifungal essential oil and a long chain alcohol from Achyranthes aspera. Phytochemistry. 1992; 31; 18111812

27. Misra T.N, Singh R.S, Pandey H.S, Prasad C, Singh B.P. Two long chain compounds from Achyranthes aspera. Phytochemistry. 1993; 33; 221-223

28. Misra T.N, Singh R.S, Pandey H.S, Prasad C, Singh S. Isolation and characterization of two new compounds from Achyranthes aspera Linn. Ind J Chem. 1996; 35B; 637-639 
29. Ali M. Chemical investigation of Achyranthes aspera Linn. Oriental J Chem. 1993; 9; 84- 85

30. Sinha S.K.P, Dogra J.V.V. A survey of plants of Bhagalpur and Santhal pargana for saponin, flavonoids and alkaloids. Int J Crude Drug Res. $2002 ; 23 ; 77-86$

31. Satyanarayana M.S, Susheela B.A, Rao N.A.N, Vijayaraghavan P.K. The proximate composition and essential amino acid content of Aghada seeds. J Food Sci Technol. $1964 ; 1 ; 26-27$

32. Gopalachari R, Dhar M.L. Chemical examination of the seeds of Achyranthes aspera Linn. J Sci Ind Res. 1952; 11B; 209-210

33. Gopalachari R, Dhar M.L. Studies in the constitution of the saponin from the seeds of Achyranthes aspera: Part I - Identification of the sapogenin. J Sci Ind Res. 1958; 17B; 276-278

34. Khastgir H.N, Sengupta S.K, Sengupta $\mathrm{P}$. The sapogenin from seeds of Achyranthes aspera Linn. J Ind Chem Soc. 1958; 35; 693-694

35. Hariharan V, Rangaswamy S. Structure of saponins A and B from the seeds of Achyranthes aspera. Phytochemistry. 1970; 9; 409-414

36. Sarkar B, Rastogi R.P. Paper chromatography of triterpenoid saponins. J Sci Ind Res. 1960; 19B; 106-107

37. Joshi M.C, Sabnis S.D. A phytochemical study of South Gujarat forests plants with special reference to the medicinal and of ethnobotanical interest. Bull Med Ethnobot Res. 1989; 10; 61-82

38. Sharma S.K, Vasudeva N, Ali M. A new aliphaticacid from Achyranthes aspera Linn. roots. Indian Journal of Chemistry. 2009; 48B; 1164-1169

39. Agrawal R.G, Pant P, Tewari L.C, Singh J, Pandey M.J, Tiwary D.N. Preliminary phytochemical screening of medicinal plants of hilly district of
U.P. Bull Med Ethnobot Res. 1989; 10; 176-186

40. Banerji A, Chadha M.S. Insect moulting hormone from Achyranthes aspera. Phytochemistry. 1970; 9; 1671-1673

41. Banerji A, Chintalwar G.J, Joshi N.K, Chadha M.S. Isolation of ecdysterone from Indian plants. Phytochemistry. 1971; 10; 22252226

42. Sushil K, Bagchi G.D, Darokar M.P. Antibacterial activity observed in the seeds of some coprophilous plants. Int J Pharmacog. 1997; 35; 179-184

43. Valsaraj R, Pushpangadan P, Smitt U.W, Andersen A, Nyman U. Antimicrobial screening of selected medicinal plants from India. J Ethnopharmacol. 1997; 58; 75-83

44. Saravanan P, Ramasamy V, Shivakumar T. Antimicrobial activity of leaf extracts of Achyranthes aspera Linn. Asian Journal of Chemistry. 2008; 20(1); 823-825

45. Thilagavathi G, Kannaian $T$. Application of Prickly chaff (Achyranthes aspera Linn.) leaves as herbal antimicrobial finish for cotton fabric used in healthcare textiles. Natural Product Radiance. 2008; 7(4); 330-334

46. Bagavan A, Rahuman A.A, Kamaraj C, Geetha K. Larvicidal activity of saponin from Achyranthes aspera against Aedes aegypti and Culex quinquefasciatus (Diptera: Culicidae). Parasitology Research. 2008; 103(1); 223-229

47. Vetrichelvian $T$, Jegadeesan $M$. Effect of alcohol extract of Achyranthes aspera Linn. on acute and subacute inflammation. Phytother Res. 2003; 17(1); 77-79

48. Gokhale A.B, Damre A.S, Kulkami K.R, Saraf M.N. Preliminary evaluation of anti-inflammatory and anti-arthritic activity of $S$. lappa, A. 
speciosa and A. aspera.

Phytomedicine. 2002; 9(5); 433-437

49. Neogi N.C, Garg R.D, Rathor R.S. Preliminary pharmacological studies on achyranthine. Indian J Pharm. $1970 ; 32 ; 43-46$

50. Vasudeva R.Y, Duddukuri G.R, Sunil B.G, Athota R.R. Immunomodulatory Activity of Achyranthes aspera on the Elicitation of Antigen-Specific Murine Antibody Response. Pharm. Biol. 2002; 40(3); 175-178

51. Rao Y.V, Chakrabarti R. Stimulation of immunity in Indian major carp Catla catla with herbal feed ingredients. Fish Shellfish Immunol. 2005; 18(4); 327-334

52. Vasudeva N, Sharma S.K. Postcoital antifertility activity of Achyranthes aspera Linn. root. J. Ethanopharmacol. 2006; 107(2); 179-181

53. Vasudeva R.Y, Das B.K, Jyotyrmayee P, Chakrabarti R. Effect of Achyranthes aspera on the immunity and survival of Labeo rohita infected with Aeromonas hydrophila. Fish Shellfish Immunol. 2006; 20(3); 263-273

54. Chakrabarti R, Vasudeva Y. Achyranthes aspera stimulates the immunity and enhances the antigen clearance in Catla catla. Int Immunopharmacol. 2006; 6(5); 782790

55. Pakrashi A, Basak B, Mookerji N. Search for antifertility agents from indigenous medicinal plants. Ind $\mathbf{J}$ Med Res. 1975; 63; 378-381

56. Prakash A.O. Potentialities of some indigenous plants for antifertility activity. Int J Crude Drug Res. 1986; 24; 19-24

57. Paul D, Bera S, Jana D, Maiti R, Ghosh D. In vitro determination of the contraceptive spermicidal activity of a composite extract of Achyranthes aspera and Stephania hernandifolia on human semen. Contraception. 2006; 73(3); 284-288

58. Shibeshi W, Makonnen E, Zerihun L, Debella A. Effect of Achyranthes aspera L. on fetal abortion, uterine and pituitary weights, serum lipids and hormones. Afr Health Sci. 2006; 6(2); 108-112

59. Kamboj V.P, Dhawan B.N. Research on plants for fertility regulation in India. J. Ethanopharmacol. 1982; 6(2); 191-226

60. Prakash A.O, Shukla S, Mathur R. Interceptive plants: Present and future aspects. Comp Physiol Ecol. 1987; 12; 157-171

61. Wadhwa V, Singh M.M, Gupta D.N, Singh C, Kamboj V.P. Contraceptive and hormonal properties of Achyranthes aspera in rats and hamsters. Planta Med. 1986; 5; 231- 232

62. Sandhyakumary K, Boby R.G, Indira M. Impact of feeding ethanolic extracts of Achyranthes aspera Linn. on reproductive functions in male rats. Indian J Exp Biol. 2002; 40(11); 1307-1309

63. Pakrashi A, Bhattacharya N. Abortifacient principle of Achyranthes aspera Linn. Indian J Exp Biol. 1977; 15(10); 856-887

64. Pakrashi A, Mookerji N, Basak B. Effect of chromatographic fraction of the plant Achyranthes aspera Linn. on female albino mice. J. Reprod Fert. 1975; 43; 127-128

65. Vasudeva N, Sharma S.K. Estrogenic and pregnancy interceptory effects of Achyranthes aspera Linn. root. African Journal of Traditional, Complementary and Alternative Medicines. 2007; 4(1); 7-11

66. Khanna A.K, Chander R, Singh C, Srivastava A.K, Kapoor N.K. Hypolipidemic activity of Achyranthes aspera Linn. in normal and triton-induced hyperlipidemic 
rats. Indian J Exp Biol. 1992; 30; 128-130

67. Girija S, Valarmathy N. Antifeedant effect of Achyranthes aspera Linn on cauliflower borer (Hellula undalis), fruit and leaf borer of cauliflower (Spodoptera litura) and Brinjal fruit borer (Leucinodes arbonalis). Biosciences Biotechnology Research Asia. 2008; 5(2); 663-672

68. Dhar M.L, Dhar M.M, Dhawan B.N, Mehrotra B.N, Ray C. Screening of Indian plants for biological activity. Part I, Indian J Exp Biol. 1968; 6; 232-247

69. Akhtar M.S, Iqbal J. Evaluation of hypoglycemic effects of Achyranthes aspera in normal and alloxandiabetic rabbits. J. Ethnopharmacol. 1991; 31; 49-51

70. Gupta S, Verma S.C, Ram A.K, Tripathi R.M. Diuretic effect of the saponin of Achyranthes aspera (Apamarga). Ind J Pharmacol. 1972; 4; 208-214

71. Ram A.K, Bhagwat A.W, Gupta S.S. Effect of saponin of Achyranthes aspera on the phosphorylase activity of rat heart. Ind J Physiol Pharmacol. 1971; 15; 107-110

72. Gupta S.S, Sanyal A.K, Chowdhury N.K. Pharmacological study of Achyranthes aspera Linn. A preliminary report. Ind $\mathrm{J}$ Physiol Pharmacol. 1965; 9; 185-188

73. Kapoor L.D. Handbook of ayurvedic medicinal plants. Inc. Florida; CRC press; 1990. 13p

74. Chakraborty A, Brantner A, Mukainaka T, Nobukuni Y, Kuchide M, Konoshima T, Tokuda $\mathrm{H}$, Nishino $\mathrm{H}$. Cancer chemo preventive activity of Achyranthes aspera leaves on Epstein-Barr virus activation and two-stage mouse skin carcinogenesis. Cancer lett. 2002; $177(1) ; 1-5$
75. Sutar N.G, Sutar U.N, Sharma Y.P, Shaikh I.K, Kshirsagar S.S. Phytochemical investigation and pharmacological screening of leaves of Achyranthus aspera Linn. as analgesic and antipyretic. Biosciences

Biotechnology Research Asia. 2008; 5(2); 841-844

76. Ammon H.P.T, Wahl M.A. Pharmacology of Curcuma longa. Planta Med. 1991; 57; 1-7

77. Eigner D, Scholz D. Ferula asafoetida and Curcuma longa in traditional medicinal treatment and diet in Nepal. J. Ethnopharmacol. 1999; 67; 1-6.

78. Ammon H.P.T, Anazodo M.I, Safayhi H, Dhawan B.N, Srimal R.C, Curcumin: a potent inhibitor of leukotriene B4 formation in rat peritoneal polymorphonuclear neutrophils (PMNL). Planta Med. 1992; 58; 26

79. Ghatak N, Basu N. Sodium curcuminate as an effective antiinflammatory agent. Indian J. Exp. Biol. 1972; 10; 235-236

80. Srihari Rao T, Basu N, Siddqui H.H. Anti-inflammatory activity of curcumin analogues. Indian J. Med. Res. 1982; 75; 574- 578

81. Bhavani Shankar T.N, Sreenivasa Murthy V. Effect of turmeric (Curcuma longa) fractions on the growth of some intestinal and pathogenic bacteria in vitro. Indian J. Exp. Biol. 1979; 17; 1363- 1366

82. Kiso Y, Suzuki Y, Watanabe N, Oshima $\mathrm{Y}, \mathrm{Hikino} \mathrm{H}$. Antihepatotoxic principles of Curcuma longa rhizomes. Planta Med. 1983; 49; 185-187

83. Hikino H. Antihepatotoxic activity of crude drugs. Yakugaku Zasshi. $1985 ; 105 ; 109-118$

84. Ramprasad C, Sirsi M, Studies on Indian medicinal plants: Curcuma longa Linn. - Effect of curcumin and the essential oils of Curcuma longa 
on bile secretion. J. Sci. Ind. Res. $1956 ; 15 ; 262-265$

85. Jentzsch K, Gonda T, Holler $\mathrm{H}$. Paper chromatographic and pharmacological investigations on Curcuma pigments. Pharm. Acta Helv. 1959; 34; 181-188

86. Platel K, Srinivasan K. Influence of dietary spices and their active principles on pancreatic digestive enzymes in albino rats. Nahrung. 2000; 44; 42-46

87. Nirmala C, Puvanakrishnan R. Protective role of curcumin against isoproterenol-induced myocardial infarction in rats. Mol. Cell. Biochem. 1996; 159; 85-93

88. Kosuge $\mathrm{T}$, Ishida $\mathrm{H}$, Yamazaki $\mathrm{H}$. Studies on active substances in the herbs used for oketsu ('stagnant blood') in Chinese medicine. III. On the anticoagulative principles in curcumae rhizoma. Chem. Pharm. Bull. (Tokyo). 1985; 33; 1499-1502

89. Srivastava R, Dikshit M, Srimal R.C, Dhawan B.N. Antithrombotic effect of curcumin. Thromb. Res. 1985; 40; 413-417

90. Rao S.D, Chandrashekhara N, Satyanarayana M.N, Srinivasan M. Effect of curcumin on serum and liver cholesterol levels in the rat. J. Nutr. 1970; 100; 1307-1315

91. Rukkumani R, Sri Balasubashini M, Menon V.P. Protective effects of curcumin and photo-irradiated curcumin on circulatory lipids and lipid peroxidation products in alcohol and polyunsaturated fatty acid-induced toxicity. Phytother. Res. 2003; 17; 925-929

92. Dhar M.L, Dhar M.M, Dhawan B.N, Mehrotra B.N, Ray C. Screening of Indian plants for biological activity: I. Indian J. Exp. Biol. 1968; 6; 232247

93. Mazumdar A, Raghavan K, Weinstein J, Kohn K.W, Pommer Y. Inhibition of human immunodeficiency virus type-1 integrase by curcumin. Biochem. Pharmacol. 1995; 49; 1165-1170

94. Reddy P, Lokesh B.R. Effect of dietary turmeric (Curcuma longa) on iron-induced lipid peroxidation in the rat liver. Food Chem. Toxicol. 1994; 32; 279-283

95. Unnikrishnan M.K, Rao M.N. Inhibition of nitric-induced oxidation of hemoglobin by curcuminoids. Pharmazie. 1995; 50; 490-492

96. Song E.K, Cho H, Kim J.S, Kim N.Y, An N.H, Kim J.A. Diarylheptanoids with free radical scavenging and hepato protective activity in vitro from Curcuma longa. Planta Med. 2001; 67; 876877

97. Phan T.T, See P, Lee S.T, Chan S.Y. Protective effects of curcumin against oxidative damage on skin cell in vitro: its implication for wound healing. J. Trauma. 2001; 51; 927-931

98. Huang M.T, Smart R.C, Wong C.Q, Conney A.H. Inhibitory effect of curcumin, chlorogenic acid, caffeic acid, and ferulic acid on tumor promotion in mouse skin by $12-\mathrm{O}-$ tetradecanoylphorbol- 13-acetate. Cancer Res. 1988; 48; 5941-5946

99. Bhaumik S, Jyothi M.D, Khar A. Differential modulation of nitric oxide production by curcumin in host macrophages and NK cells. FEBS Lett. 2000; 483; 78-82

100. Surh Y.J, Chun K.S, Cha H.H, Han S.S, Keum Y.S, Park K.K, Lee S.S. Molecular mechanism underlying chemopreventive activities of antiinflammatory phytochemicals: down regulation of COX-2 and iNOS through suppression of NF- $k \mathrm{~B}$ activation. Mutat. Res. 2001; 480481; 243-268

101. Kuo M.L, Huang T.S, Lin J.K. Curcumin, an antioxidant and antitumor promoter, induces apoptosis in human leukemia cells. Biochim. Biophys. Acta. 1996; 1317; 95-100 
102. Goel A, Boland C.R, Chauhan D.P. Specific inhibition of cyclooxygenase-2(COX-2)

expression by dietary curcumin in HT- 29 human colon cancer cells. Cancer Lett. 2001; 172; 111-118

103. Shao Z.M, Shen Z.Z, Liu C.H, Sartippour M.R, Go V.L, Heber D, Nguyen M. Curcumin exerts multiple suppressive effects on human breast carcinoma cells. Int. J. Cancer. 2002; 98; 234-240

104. Choudhuri T, Pal S, Aggarwal M.L, Das T, Sa G. Curcumin induces apoptosis in human breast cancer cells through p53- dependent Bax induction. FEBS Lett. 2002; 512; 334-340

105. Chandra D, Gupta S.S. Antiinflammatory and antiarthritic activity of volatile oil of Curcuma longa (Haldi). Indian J. Med. Res. $1972 ; 60 ; 138-142$

106. Lutomski J, Kedzia B, Debska W. Effect of an alcohol extract and of active ingredients from Curcuma longa on bacteria and fungi. Planta Med. 1974; 26; 9-19

107. Banerjee A, Nigam S.S. Antimicrobial efficacy of the essential oil of Curcuma longa. Indian J. Med. Res. 1978; 68; 864866

108. Arora R.B, Basu N, Kapoor V, Jain A.P. Anti-inflammatory studies on Curcuma longa (Turmeric). Indian J. Med. Res. 1971; 59; 1289-1295

109. Garg S.K. Effect of Curcuma longa (rhizomes) on fertility in experimental animals. Planta Med. 1974; 26; 225-227

110. Dixit V.P, Jain P, Joshi S.C. Hypolipidaemic effects of Curcuma longa L and Nardostachys jatamansi DC in triton-induced hyperlipidaemic rats. Indian J.
Physiol. Pharmacol. 1988; 32; 299304

111. Kuttan R, Bhanumathy P, Nirmala K, George M.C. Potential anticancer activity of turmeric (Curcuma longa). Cancer Lett. 1985; 29; 197202

112. Misra S.K, Sahu K.C. Screening of some indigenous plants for antifungal activity against dermatophytes. Indian J. Pharmacol. 1977; 9; 269-272

113. Ferreira L.A.F, Henriques O.B, Andreoni A.A.S, Vital G.R.F, Campos M.M.C, Habermehl G.G, Moraes V.L.G. Antivenom and biological effects of ar-turmerone isolated from Curcuma longa (Zingiberaceae). Toxicon. 1992; 30; 1211-1218

114. Azuine M.A, Bhide S.V. Adjuvant chemoprevention of experimental cancer: catechin and dietary turmeric in forestomach and oral cancer models. J. Ethnopharmacol. 1994; 44; 211-217

115. Lee C.J, Lee J.H, Seok J.H, Hur G.M, Park Y.C, Seol I.C, Kim Y.H. Effects of baicalein, berberine, curcumin and hespiridin on mucin release from airway goblet cells. Planta Med. 2003; 69; 523-526

116. Kapoor L.D. Handbook of Ayurvedic Medicinal Plants Florida; CRC Press Boca Raton; 1990. 185p

117. Ruby A.J, Kuttan G, Dinesh Babu K, Rajasekharan K.N, Kuttan R. Antitumor and antioxidant activity of natural curcuminoids. Cancer Lett. 1995; 94; 79-83

118. Vopel G, Gaisbaver M, Winkler W. Phytotherapie in der Praxis. Kolu; Deutscher Arzteverlag; 1990. 74p

119. Roughley P.J, Whiting D.A. Experiments in the biosynthesis of curcumin. J. Chem. Soc. 1973; 20; 2379-2388 